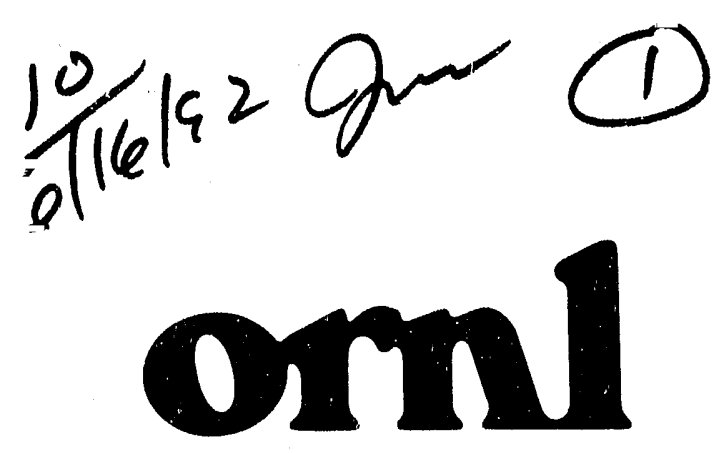

OAK RIDGE NATIONAL LABORATORY

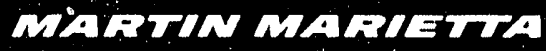

ORNL/TM-11965

\title{
Oak Ridge Gaseous Diffusion Plant Biological Monitoring and Abatement Program for Mitchell Branch
}

\author{
J. M. Loar \\ S. M. Adams \\ L. A. Kszos \\ M. G. Ryon \\ J. G. Smith \\ G. R. Southworth \\ A. J. Stewart
}

Environmental Sciences Division

Publication No. 3779

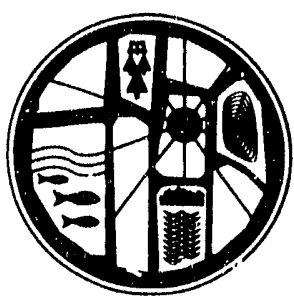

MARTIN MARIETTA ENERGY SYSTEMS, INC.

FOR THE UNITED STATES 
This report has been reproduced directly from the best available copy.

Available to DOE and DOE contractors from the Office of Scientific and Technical Information, P.O. Box 62, Oak Ridge, TN 37831; prices available from (615) 576-8401, FTS 626-8401.

Available to the public from the National Technical Information Service, U.S. Department of Commerce, 5285 Port Royal Rd., Springfieid, VA 22161.

This report was prepared as an account of work sponsored by an agency of the United States Government. Neither the United States Government, nor any agency thereof, nor any of their employees, makes any warranty, express or implied, or assumes any legal liability or responsibility for the accuracy, completeness, or usetulness of any information, apparatus, product, or process disclosed, or represents that its use would not intringe privately owned rights. Reference herein to any specific commercial product, process, or service by trade name, trademark, manufacturer, or otherwise, does not necessarily constitute or imply its endorsemant, recommendation, or favoring by the United States Government or any agency thereof. The views and opinions of authors expressed herein do not necessarily state or reflect those of the United States Government or any agency thereof. 


\title{
OAK RIDGE GASEOUS DIFFUSION PLANT BIOLOGICAL MONITORING AND ABATEMENT PROGRAY FOR MITCHELL BRANCH
}

\author{
J. M. Loar \\ S. M. Adams \\ L. A. Kszos \\ M. G. Ryon \\ J. G. Smith \\ G. R. Southworth \\ A. J. Stewart
}

Environmental Sclences Division Publication No. 3779

Manuscript Completed--December 1986

Date Published--January 1992

\author{
Prepared for \\ J. G. Rogers, Environmental Coordinator \\ Health, Safety and Environmental Affairs Division \\ Oak Ridge Gaseous Diffusion Plant \\ Oak Ridge, Tennessee 37831 \\ Prepared by the \\ OAK RIDGE NATIONAL LABORATORY \\ Oak Ridge, Tennessee 37831-625s \\ managed by \\ MARTIN MARIETTA ENERGY SYSTEMS, INC. \\ for the \\ U.S. DEPARTMENT OF ENERGY \\ under contract DE-AC05-840R21400
}


PREFACE .............................. v v

ACKNOWLEDGMENTS . . . . . . . . . . . . . . . . . . . . . . . . vii

ABSTRACT . . . . . . . . . . . . . . . . . . . . . . ix

ACRONYMS . . . . . . . . . . . . . . . . . . . . . . $\mathrm{x} 1$

1. INTRODUCTION (J. M. LOAT) . . . . . . . . . . . . . . . 1

1.1 OBJECTIVES . . . . . . . . . . . . . . . . . . . . . . . 1

1.2 DESCRIPTION OF STUDY AREA . . . . . . . . . . . . . . . . 1

2. BIOLOGICAL MONITORING TASKS . . . . . . . . . . . . . . . . . . 7

2.1 TOXICITY MONITORING (TASK 1) (L. A. Kszos and
A. J. Stewart) . . . . . . . . . . . . 7

2.1 .1 Introduction . . . . . . . . . . . . . . . . 7

2.1 .2 Study Design . . . . . . . . . . . . . . . . . . 8

2.1.3 Description of Subtasks .............. 9

2.1 .4 Sampling .. . . . . . . . . . . . . . . 10

2.1.5 Facilities .................. . 10

2.2 BIOACCUMULATION STUDIES (TASK 2) (G. R. Southworth) . . . 11

2.3 BIOLOGICAL INDICATORS OF CONTAMINANT -

RELATED STRESS (TASK 3) (S. M. Adams) . . . . . . . . . . 13

2.3.1 Introduction . . . . . . . . . . . . . . . . . . . 13

2.3.2 Advantages and Uses of Blological Indicators . . . 14

2.3.3 Sampling Approach and Design . . . . . . . . . . . 17

2.4 INSTREAM MONITORING (TASK 4) . . . . . . . . . . . . . . . 22

2.4.1 Introduction . . . . . . . . . . . . . . . . . . . 22

2.4 .2 Benthic Macroinvertebrates (Subtask 4a)
(J. G. Smith) .............. . . . 22

2.4.3 Fishes (Subtask 4b) (M. G. Ryon) . . . . . . . . . 24

3. REFERENCES . . . . . . . . . . . . . . . . . . 27

APPENDIX A: IOCATION OF CORBICULA COLLECTION SITE AND

R.ESULTS OF CHEMICAL ANALYSES . . . . . . . . . . . 33 


\section{PREFACE}

The proposed Biological Monitoring and Abatement Program (BMAP) for Mitchell Branch, as outlined in this document, will be conducted for the duration of the modified National Pollutant Discharge Elimination System (NPDES) permit issued for the Oak Ridge Gaseous Diffusion Plant (ORGDP; currently the Oak Ridge K-25 Site) on September 11, 1986. The basic approach to biological monitoring used in this program was developed by staff in the Environmental Sciences Division at Oak Ridge National Laboratory (ORNL) at the request of ORGDP. The proposed BMAP is based on preliminary discussions held on October 14-15, 1986, between staff of Martin Marietta Energy Systems, Inc. (ORNL and ORGDP), the U.S. Environmental Protection Agency (EPA), and the State of Tennessee Department of Health and Environment (TDHE), currently the Department of Environment and Conservation. The composition of existing effluent streams entering Mitchell Branch, a small stream that drains the northeast portion of the OPGDP site, will be altered shortly after the modified NPDES permit is issued, so baseline (preoperational) conditions in Mitchell Branch may exist only for the next few months. Consequently, preliminary sampling of the benthic invertebrate and fish populations, as required by Task 4 (see sect. 2.4), was initiated in August and September 1986 respectively.

Although details are provided of the specific procedures to be used in the initial stages of BMAP, experimental designs associated with studies that will be implemented after the first year are described in less detail. The overall strategy is to use the results obtained in the initial characterization studies to define the scope of future monitoring efforts. Such efforts may require more-intensive sampling than initially proposed in some areas (e.g., additional toxicity testing if initial results indicate poor survival or growth) and a reduction in sampling intensity in others (e.g., reduction in benthic invertebrate sampling frequency from monthly to bimonthly or quarterly after the first year). By using the results of previous monitoring efforts to define the needs and short-term goals of future studies, an effective, integrated monitoring program can be developed to assess the impacts of ORGDP operations on the ecological integrity of Mitche1I Branch. 
As noted, a BMAP was prepared and submitted to TDHE and EPA in late 1986. Except where additional clarification could be provided by relatively minor editorial changes, the BMAP presented in this report is the same as that described in the previous draft report that was submitted to the regulatory agencies for review. To preserve historical accuracy, any changes that occurred after 1986, whether they be substantial modifications in plant operations or even changes in the name of a facility or agency, are not included in the body of this report. However, the final version described here does cite recently published reports (1.e., after 1986) if they were listed as draft documents in the original version. Also, some additional information (e.g., Appendix A) was provided in the final version in response to written comments submitted by TDHE in March 1987. 


\section{ACKNOWLEDGMENTS}

We thank Byron F. Clark, affiliated at the time of manuscript preparation with the Tennessee Department of Health and Environment, for his review of the draft report of December 1986. The information presented in response to his written comments has been incorporated into this final report in Sects. 2.2 and 2.3 .3 and in a newly created appendix.

We are also grateful to T. L. Ashwood and S. W. Christensen for their technical review of the revised document.

This project was funded by the Department of Environmental Management of the Heaith, Safety and Environmental Affairs Division at the Oak Ridge Gaseous Diffusion Plant (currently the Oak Ridge K-25 Site). Oak Ridge National Laboratory and the Oak Ridge K-25 Site are managed by Martin Marietta Energy Systems, Inc., for the U.S. Department of Energy under contract DE-AC05-840R21400. 
A proposed Biological Monitoring and Abatement Program (BMAP) for the Oak Ridge Gaseous Diffusion Plant (ORGDP; currently the Oak Ridge K-25 Site) was prepared in December 1986, as required by the modified National Pollutant Discharge Elimination System (NPDES) permit that was issued on September 11, 1986. The proposed BMAP described in this report is based on preliminary discussions held on October 14-15, 1986, between staff of Martin Marietta Energy Systems, Inc. [at Oak Ridge National Laboratory and ORGDP], the U.S. Environmental Protection Agency, and the State of Tennessee Department of Health and Environment (currently the Department of Environment and Conservation). Because the composition of some effluents discharged to Mitchell Branch was expected to be altered shortly after the modified NPDES permit was issued, preliminary sampling of the benthic invertebrate and fish communities was initiated in August and September 1986, respectively, to take advantage of the potentially brief baseline or preoperational period.

The proposed BMAP consists of four tasks that reflect different but complementary approaches to evaluating the effects of ORGDP effluents on the ecological integrity of Mitchell Branch. These tasks include

(1) ambient toxicity testing, (2) bioaccumulation studies, (3) biological indicator studies, and (4) ecological surveys of the benthic invertebrate and fish communities. This overall plan combines established protocols with state-of-the-art biological monitoring techniques to assess compliance and monitor ecological recovery. More specifically, BMAP will determine whether the effluent limits established for ORGDP protect the designated use of the receiving stream (Mitchell Branch) for growth and propagation of fish and aquatic 1 ife. Another objective of the program is to document the ecological effects resulting from various pollution abatement projects, such as the Central Neutralization Facility. 


\section{ACRONYMS}

BMAP

CNF

DOE

EPA

GLM

MIK

NPDES

ORGDP

ORNL

PAHs

PCB

$\mathrm{SD}$

TDHE

TSCA
Biological Monitoring and Abatement Program

Centra1 Neutralization Facility

U.S. Department of Energy

U.S. Environmental Protection Agency

general linear model

Mitchell Branch kilometer

National Pollutant Discharge Elimination System

Oak Ridge Gaseous Diffusion Plant (now the Oak Ridge

K-25 Site)

Oak Ridge National Laboratory

polycyclic aromatic hydrocarbons

polychlorinated biphenyl

storm drain

Tennessee Department of Health and Environment (now

Tennessee Department of Environment and Conservation)

Toxic Substances Control Act 


\section{INTRODUCTION}

On September 11, 1986, a modified National Pollutant Discharge Elimination System (NPDES) permit was issued for the Oak Ridge Gaseous Diffusion Plant (ORGDP), an enriched-uranium production facility operated by Martin Marietta Energy Systems, Inc., for the U.S. Department of Energy (DOE). As specified in Part III (L) of the permit, a plan for the biological monitoring of Mitchell Branch (K-1700 stream) shall be submitted to the U.S. Environmental Protection Agency (EPA) and the Tennessee Department of Health and Environment within 90 days of the effective date of the permit modifications. The Blological Monitoring and Abatement Program (BMAP), as outlined in Sect. 2, has been developed to meet this requirement.

\subsection{OBJECTIVES}

The proposed BMAP was developed to meet two major objectives. First, studies were designed to provide sufficient data to determine whether the effluent limitations established for ORGDP protect and maintain the use of Mitchell Branch for growth and propagation of fish and aquatic life. A second major objective of the biological monitoring that will be conducted on Mitchell Branch is to document the effects on stream biota resulting from operation of major new pollution abatement facilities, including the Central Neutralization Facility (CNF) and the Toxic Substances Control Act (TSCA) Incinerator (Sect. 1.2). Unlike the first objective, in which biological monitoring is used to determine compliance, this objective employs biological criteria to evaluate the effects of specific pollution control measures.

\subsection{DESCRIPTION OF STUDY AREA}

Mitchell Branch, a small second-order tributary of Poplar Creek, is located near the northeast boundary of ORGDP (Fig. 1). With a drainage area of $1.78 \mathrm{~km}^{2}$, Mitchell Branch is similar in size to the $2.59-\mathrm{km}^{2}$ 
ORNL DWG 91M-15137

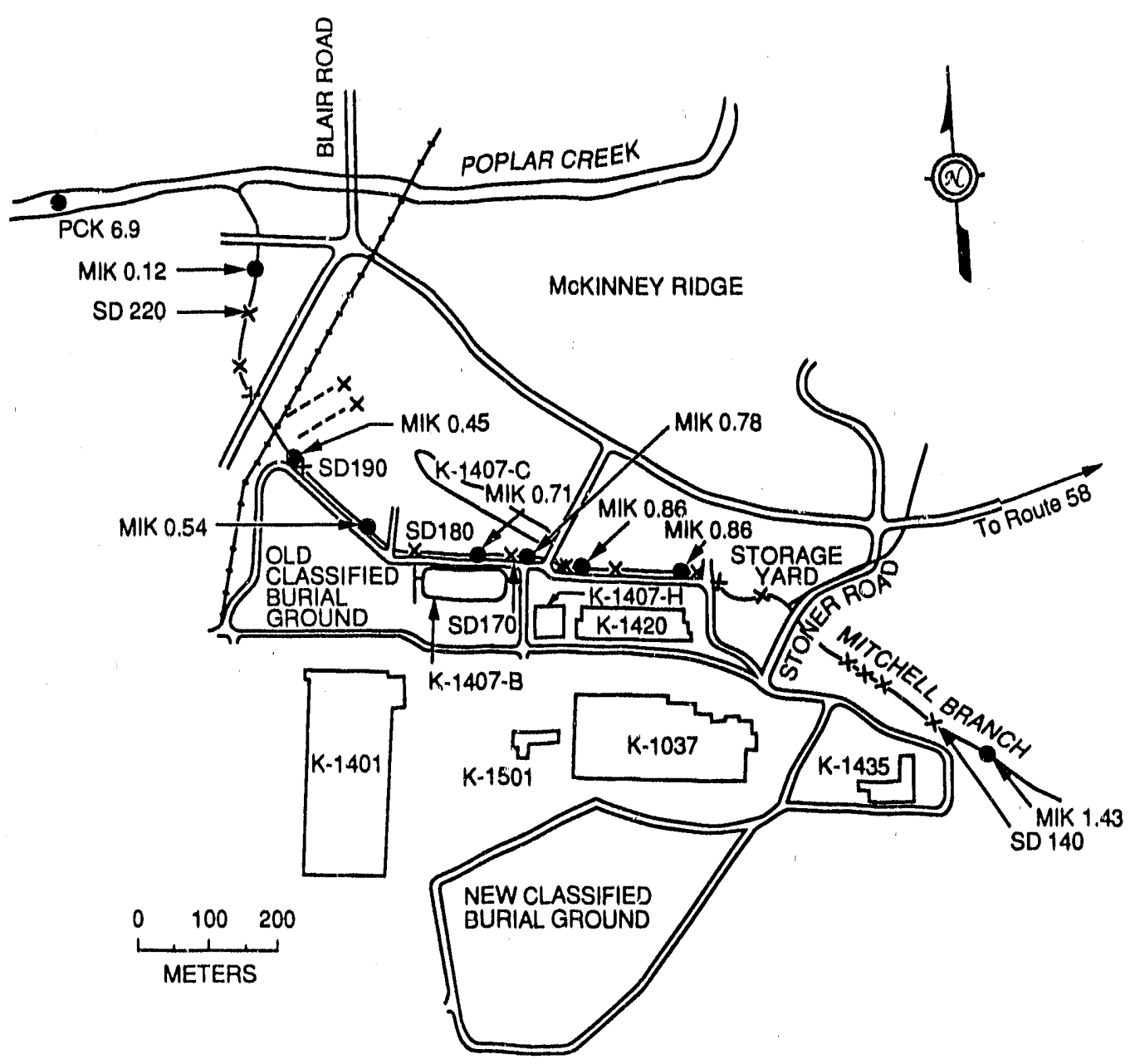

Fig. 1. Map of Mitchell Branch and the northeast region of the Oak Ridge Gaseous Diffusion Plant, showing Blological Monitoring and Abatement Program sampling sites in relation to selected storm drains (SDs). 
watershed of Grassy Creek at the reference site (Grassy Creek kilometer 2.4) used in studies conducted on Bear Creek (Southworth 1992). The mouth of Mitchell Branch is located near Poplar Creek kilometer 4.5, $-150 \mathrm{~m}$ downstream of the Blair Road bridge and $1000 \mathrm{~m}$ downstream of the mouth of East Fork Poplar Creek.

Effluent discharges to Mitchell Branch

Liquid effluents are discharged to Mitchell Branch at several locations (Fig. 1). The major effluent stream is the discharge from the K-1407-B holding pond, a 0.54-ha retention basin constructed primarily for solids settling and $\mathrm{pH}$ control. The pond receives (1) uranium compounds and acidic/caustic wastes discharged from the decontamination and recovery facility (Building $k-1420$ ), (2) neutralized wastes from the metals preparation facility (K-1401), (3) blowdown from the recirculating water system of the barrier manufacturing facility ( $K-1037)$, (4) caustic wastes from the steam plant water treatment process, and (5) coal yard runoff. The overflow discharge from the K-1407-B holding pond also receives once-through cooling water prior to entering Mitche11 Branch. Some coal yard runoff and boiler blowdown are discharged via storm drain (SD) 170 to Mitchell Branch just upstream of the K-1407-B pond (Fig. 1). Finally, several storm drains contribute suspended particulates to the stream during rainfall events.

Leachate from waste disposal sites (i.e., area-source discharges) may also enter the stream. The old classified burial ground, a 1.50-ha site located $120 \mathrm{~m}$ west of the $\mathrm{K}-1407-\mathrm{B}$ pond, was formed by filling in a large swampy area that drained into Mitchell Branch. It contains both radioactive and nonradioactive wastes; classified wastes are currently disposed of at a site just south of the K-1501 steam plant (Fig. 1). An ephemeral stream drains this site, which is located within the Mitche11 Branch watershed. The $\mathrm{K}-1407-\mathrm{C}$ retention basin has an area of 0.80 ha and is located $-120 \mathrm{~m}$ north of the $\mathrm{K}-1407-\mathrm{B}$ pond. It was constructed in 1973 and received dredged material from other holding ponds, including K-1407-B. The basin contains dewatered sludge with low 
levels of radioactivity, primarily uranium. Although the basin has no surface effluent, a groundwater plume extending from the pond toward the stream has been detected (Ashwood et al. 1986).

Several significant projects will be implemented in the near future that will alter the existing water quality of Mitchell Branch. The CNF, which is scheduled to be on-line in 1987, will treat the effluent from the decontamination and recovery facility, the metals preparation facility, and the TSCA incinerator (Building K-1435), which will be operational in July 1987 for disposal of hazardous and polychlorinated biphenyl ( $P C B$ ) wastes. A second major waste stream to the CNF consists of coal yard runoff and boller blowdown from the K-1501 steam plant. Modifications will be made to the CNF in 1988 that will permit replacement of the K-1407-B holding pond. Closure of the K-1407-B pond under the Resource Conservation and Recovery Act is scheduled for November 1988 .

Sediment contamination

The sediments of Mitchell Branch ( $K-1700$ stream) contain metals, organic contaminants, and radionuclides discharged over many years of operation. Elevated levels of uranium isotopes, As, Cd, Cr, $\mathrm{Ni}, \mathrm{Pb}, \mathrm{Se}$, $\mathrm{Ag}$, and $\mathrm{Zn}$ were observed in 1985 by Ashwood et al. (1986). Polycyclic aromatic hydrocarbons (PAHs) were detected in the sediments at two of five sampling sites and are probably derived from coal yard runoff. Elevated levels of contaminants were detected both upstream and downstream of the discharge from the K-1407-B pond.

Sampling sites

Seven permanent sampling sites were selected on Mitchell Branch (Fig. 1 and Table 1). These sites are above and below three discharge locations (SD 170, SD 180, and SD 190 in Fig. 1): a small stream that receives boiler blowdown and coal yard runoff (SD 170), the effluent discharges from the K-1407-B holding pond (SD 180), and the stream that receives storm runoff in the vicinity of the old classified burial ground (SD 190). The sampling sites for the toxicity monitoring and instream monitoring tasks (Tasks 1 and 4, respectively) overlap: each task includes sampling at six of the seven sites. 
Table 1. Location and description of the seven biological monftoring sites on Mitchell Branch

\begin{tabular}{lll}
\hline Site & \multicolumn{1}{c}{ Description } \\
\hline MIK 0.12 & At NPDES monitoring station & BMAP task \\
MIK 0.45 & $45 \mathrm{~m}$ below SD 190 & $1 \mathrm{a}, 2,3$ \\
MIK 0.54 & $90 \mathrm{~m}$ below SD 180 & $1 \mathrm{a}, 4 \mathrm{a}, 4 \mathrm{~b}$ \\
MIK 0.71 & $50 \mathrm{~m}$ below SD 170 & $1 \mathrm{a}, 4 \mathrm{a}, 4 \mathrm{~b}$ \\
MIK 0.78 & $20 \mathrm{~m}$ above SD 170 & $1 \mathrm{a}, 4 \mathrm{a}, 4 \mathrm{~b}$ \\
MIK 0.86 & $100 \mathrm{~m}$ above SD 170 & $4 \mathrm{a}, 4 \mathrm{~b}$ \\
MIK 1.43 & $\begin{array}{l}\text { Reference (control) site above } \\
\text { ORGDP; 650 m above SD } 170\end{array}$ & $1 \mathrm{a}, 4 \mathrm{a}$ \\
\hline
\end{tabular}

aitchell Branch kilometer (MIK) nomenclature for sites refers to the distance in kilometers above the confluence of Mitchell Branch with Poplar Creek.

bNPDES - National Pollutant Discharge Elimination System; ORGDP Oak Ridge Gaseous Diffusion Plant; SD - storm drain.

${ }^{\circ}$ BMAP task numbers refer to the Biological Monitoring and Abatement Program tasks and subtasks described in this report. 


\section{BIOLOGICAL MONITORING TASKS}

The effluent discharges to Mitchell Branch are complex, consisting of trace elements, organic chemicals, and radionuclides in addition to various conventional pollutants. Moreover, the composition of these effluent streams will be changing over time as various pollution abatement measures are implemented over the next several years. Although contaminant inputs to the stream originate primarily as point suurces from existing plant operations, area sources, such as the classified burial grounds and the K-1407-C holding pond (Sect. 1.2), can not be eliminated as potential sources of contaminants.

Suci: environmental complexities require a nultitiered, yet integrated approach to biological monitoring. Consequently, the BMAP for Mitchell Branch consists of four major tasks: Toxicity Monitoring (Sect. 2.1), Bioaccumulation Studies (Sect. 2.2), Biological Indicator Studies (Sect. 2.3), and Instream Monitoring (Sect. 2.4). These tasks combine well-established monitoring metrods with more-innovative stateof-the-art techniques to evaluate regulatory compliance.

\subsection{TOXICITY MONITORING (TASK 1)}

\subsubsection{Introduction}

Toxicity testing has become an integral cumponent of the NPDES compliance on the Oak Ridge Reservation (Loar et al. 1989, 1991). EPA supports the use of test organisms to determine the acute or chronic toxicity of a test water (EPA 1985). Test waters may include specific effluents or ambient stream sites. The toxicity tests have several advantages over chemical analyses. They (1) are rapid and economical; (2) can predict the toxicity of complex mixtures; (3) can detect toxic materials that may not be typically monitored; and (4) are useful in determining the toxicity of test waters to instream biota.

The purpose of this task is to monitor the toxicity of Mitchell Branch water and selected point-source discharges to aquatic organisms. 


\subsubsection{Study Design}

The toxicity monitoring task consists of three subtasks:

(1a) ambient toxicity tesis, (1b) effluent toxicity teats, and

(1c) point-source evaluation. Subtasks $1 a$ and $1 b$ will utilize the fathead minnow (Pimephales promelas) survival and growth test and the Ceriodaphnia survival and reproduction test, as designed by EPA (Horning and Weber 1985). The two tests run concurrently, last for $7 \mathrm{~d}$, and are designed to predict the chronic toxicity of a test water. Subtask 1c will utilize elther the 7-d chronic toxicity tests or acute (48-h) toxicity tests with fathead minnows and Cerlodaphnia (Peltier and Weber 1985).

Each test with ambient water or effluents will include a dilution series unless full-strength samples are demonstrated to be nontoxic. The lowest-observed-effect concentration and the no-observed-effect concentration will be calculated for each test with a dilution series. These calculations will be based on data for survival, growth, and (for Ceriodaphnia) reproduction in test samples, control water, and/or samples from roference streams (Horning and Weber 1985). When only full-strength samples are tested, results will be reported as mortality, growth, and (for Ceriodaphnia) reproduction values in samples, control water, and reference streams.

One site upstream of ORGDP operations on Mitchell Branch will serve as a reference site. However, due to the variability of the flow in upper Mitchell Branch, the reference site will not serve as a source of dilution water or as a control. Dechlorinated tap water will be used as a control and as dilution, water for fathead minnows but will not be used with Ceriodaphnia because of the difficulty in obtaining satisfactory reproduction. Instead, hard reconstituted water will be used for the Ceriodaphnia tests.

Cadmium chloride or potassium dichromate will be used as a reference toxicant. A 24 -h static test will be conducted monthly with fathead minnow larvae and Ceriodaphnia from stock cultures to determine the health of the organisms. Control charts will be maintained to determine if the response of the test organisms falls outside of the acceptable range (Horning and Weber 1985). If the resul.ts are 
unacceptable, the biomonitoring tests will be considered invalid and will be repeated.

\subsubsection{Description of Subtasks}

Ambient toxicity tests (Subtask la)

Subtask la will monitor ambient water toxicity of Mitchell Branch using the 7-d fathead minnow and Ceriodapinia toxicity tests described in Sect. 2.1.2. Six sites along the creek which closely correspond to those utilized in the instream monitoring task (Sect. 2.4) will be sampled (Table 1 and Fig. 1). The sites will be located at the NPDES weir above the confluence with Poplar Creek [site Mitchel1 Branch kilometer (MIK) 0.12] and at kilometers (upstream from Poplar Creek, $0.45,0.54,0.71,0.86$, and 1.43 (above ORGDP operations). The site at kilometer 1.43 will serve as a reference. The results obtained during the first year w11l be evaluated to determine if sampling frequency or the number of sites can be reduced.

Effluent toxicity tests (Subtask 1b)

Subtask $1 \mathrm{~b}$ will measure the toxicity of selected effluents to fathead minnows and Ceriodaphnia using the 7-d chronic toxicity tests. As stated in the NPDES permit, the effluent from pond K-1407-B will be tested every other month. Once ponds K-1407-E and K-1407-F discharge directly into Mitchell Branch, they will also be monitored every other month. In the interim, ponds $E$ and $F$ will be monitored quarterly. In addition, as now facilities go on-line (e.g., the CNF and the TSCA incinerator), their specific effluent streams will be monitored.

Point-source evaluation (Subtask 1c)

As toxicity information accumulates from the ambient toxicity testing (see Subtask 1a) sites on Mitchell Branch, acute or chronic toxiclty tests will be conducted to determine point sources of toxicity. We will also periodically monitor two effluents not covered in the NPDES permit: (1) once-through cooling water that is currently discharged to the K-1407-B effluent stream below the pond outfall and (2) the stream (SD 190) draining the old classified burial grounds (Fig. 1). 


\section{1 .4 Samp1Ing}

Samples will be collected daily during the $7 \mathrm{~d}$ of the test from Mitchell Branch and effluent sources and transported to the Toxicity Testing Laboratory at Oak Ridge National Laboratory (ORNL) for testing. Refrigerated $24-\mathrm{h}$ composite samples will be used for subtasks $1 \mathrm{~b}$ and $1 \mathrm{c}$. Grab samples will be used for Subtask la except at the NPDES site (MIK 0.12), where a 24-h composite sample will be used.

\section{1 .5 Facilities}

Water supplies

Dechlorinated process (tap) water will be used for culturing fathead minnows and as dilution water for tests with fathead minnows. This water source has been used since 1980 in the Toxicity Testing Laboratory and has been found acceptable for growth and reproduction of fathead minnows (Loar et al. 1989). Reconstituted watec prepared from deionized distilled water will be used for culturing Ceriodaphnia and for tests with Ceriodaphnia (Horning and Weber 1985). Deviations from the method described by Horning and Weber (1985) which have been found to improve the quality of the reconstituted water are (1) aeration for 48 -h and (2) spiking the water with food after $24-h$ of aeration.

\section{Temperature controls}

Water baths will be used to control the temperature of fish and Cerlodaphnia stocks and of tests with both species. Temperature will be maintained at $25 \pm 2^{\circ} \mathrm{C}$.

\section{Instrumentation/chemical analyses}

Instruments that will be used during this study include (1) DigiSense thermometers (Cole Palmer), (2) microprocessor $\mathrm{pH} / \mathrm{millivolt}$ meter (Orion Research Model 811), (3) conductance meter (YSI Model 32), (4) microbalance (Cahn Model C-30), (5) analytical balance (Mettler Model AE163), (6) dissolved oxygen meter (VWR Scientific), and (7) zoom stereomicroscope (Wild Model M8). All instruments except for the microscopes will be calibrated before daily use. 
Chemical analyses performed dally in confunction with the tests are alkalinity, $\mathrm{pH}$, conductivity, hardness, and dissolved oxygen. Methods will follow those described in Standard Methods for the Examination of Water and Wastewater (APHA et al, 1981)

Computer/statistics

IBM 3033 (currently 3090) and DEC mainframes will be used to analyze and archive data. A Hewlett Packard (Model HP-41C/41CV) programmable calculator w111 be used in some data analyses. An IBM-PC personal computer will be used for data entry and report preparation.

Fathead minnow survival and growth will be analyzed using SAS-GLM (general linear models) procedure and Dunnett's test (Steel and Torrie 1960). Ceriodaphnia test results will be analyzed using Fisher's Exact Test (for survival) (Horning and Weber 1985) and the SAS-GLM procedure.

\subsection{BIOACCUMULATION STUDIES (TASK 2)}

Sediments from Mitchell Branch contain elevated levels of metals, organics, and radionuclides (Ashwood et al. 1986). The objectives of this task are to determine which, if any, of these substances accumulate to unacceptable levels in biota inhabiting the stream and to document any changes in elevated contaminant levels that result from changes in waste management practices.

Preliminary sampling indicates the presence of low numbers of small fish in Mitchel1 Branch, including species such as redbreast sunfish (Sect. 2.4.3), that are used in bioaccumulation monitoring near the Oak Ridge Y-12 Plant and ORNL (Loar et al. 1989, 1991). If adequate numbers of larger ( $>40-g$ ) sunfish can be collected from Mitchell Branch, these will be munitored once yearly for a broad spectrum of organic and inorganic contaminants and radionuclides. Levels of contaminants found in these fish will be compared with levels in fish from reference streams and background levels measured in other studies and will also be compared with maximum permissible concentrations derived in risk assessment screening protocols (Hoffman et al. 1984). 
Since adequate numbers of fish of suitable size for analyses may not be found in Mitchell Branch, it may be necessary to introduce fish to the stream. In such a case, identifiable fish (tagged, fin-clipped, or sterile hybrids) w111 be introduced to the pool above the NPDES monitoring weir (site MIK 0.12). After they have spent 4-6 months in the stream, the fish will be sampled and analyzed for contaminants. If stocked fish will not remain in the stream, it may be necessary to construct enclosures to maintain fish in Mitchell Branch for this task and for the biological indicator studies (Sect. 2.3).

While fish are of primary interest in bioaccumulation studies due to their potential consumption by the public, other organisms have advantages for monitoring specific compounds. The Asiatic clam (Corbicula fluminea) rapidly takes up metals and organics from water and accumulates organics, such as PAHs, that are rapidly metabolized and excreted (and therefore not accumulated) by fish. While Corbicula are common in most waters of East Tennessee, they do not appear to inhabit Mitchell Branch. Therefore, clams will be introduced in cages and maintained for 30-60 d before being sampled and analyzed for organic priority pollutants. Although Physa was considered for this study, several factors made introduced Corbicula a logical choice for bioaccumulation studies in Mitchell Branch: the larger size of Corbicula species; the ease of collecting, transporting, and removing tissue from the clams; and their use in other bioaccumulation studies.

Further information concerning Corbicula sampling is found in Appendix A. The Corbicula used in bioaccumulation studies at ORGDP, the Oak Ridge Y-12 Plant, and ORNL are obtained from a site on Beaver Creek near Karns, Tennessee (Fig. A-1). Results of analyses for PCBs, PAHs, and other organics in clams from this site are presented in Tables A-1 and A-2. Very low levels of PCBs and several PAHs were detected in the clams (Table A-1). Such levels were low enough to provide a good baseline for the use of these clams as introduced organisms in bioaccumulation studies in Mitchell Branch. Naphthalene and anthracene were reported at concentrations $\geq 1 \mu \mathrm{g}$ wet wt in one sample analyzed by high-performance liquid chromatography using fluorescence detection (Table A-1), a sensitive but nonconfirmatory procedure. Subsequent 
analyses by gas chromatographic mass spectrometry did not indicate the presence of these compounds at $\geq 1 \mu \mathrm{g} / \mathrm{g}$ (Table $\mathrm{A}-2$ ). Each time that clams are Introduced Into Mitchell Branch, a control group of Corbicula from Beaver Creek will be collected for analysis along with the test organisms. This procedure establishes a baseline with which the test results can be compared.

If any contaminants are found to be elevated in the broad-spectrum screening analyses, those substances will be monitored in fish or clams (whichever is more appropriate) every 6 months for the duration of BMAP. This will provide an opportunity to assess the effectiveness of remedial actions in eliminating the sources of those contaminants.

\subsection{BIOLOGICAL INDICATORS OF CONTAMINANT-RELATED STRESS (TASK 3)}

\section{3 .1 Introduction}

This task will involve the selection and application of various biological indicators to evaluate the effects of water quality on fish populations in Mitchell Branch. Within the context of this study, biological indicators (or bioindicators) are defined as selected components or variables of organisms, populations, or communities that respond in biologically meaningful ways to changes in the environment. Bioindicators will be used in this task to address two major objectives: (1) identification and characterization of impacts on aquatic biota and (2) collection of baseline data that can be used to evaluate the effectiveness of remedial actions. The application of selected bioindicators, in conjunction with the toxicity monitoring and instream monitoring tasks (Sects. 2.1 and 2.4 , respectively), can be used to address these objectives in a timely and cost-effective manner.

In biomonitoring programs designed to evaluate compllance with established water quality standards and to assess potential environmental effects, short-term laboratory toxicity tests (e.g., $\mathrm{LC}_{50}$ tests) are commonly used to determine the time required to elicit various levels of mortality in standard test organisms. This approach is generally acceptable for screening toxicant effects on a short-term basis (i.e., hours or days), but in most cases these criteria may be 
less appropriate for predicting or evaluating the longer-term, chronic effects of pollutants on biolsgical populations and communities (1.e., growth, reproductive potantial, trophic level status, abundance, and diversity) (NRC 1981). Capabilities are needed, therefore, to identify and quantify responses of aquatic organisms and biological communities to sublethal chronic exposures before adverse, ix :versible, or obviously undesirable effects on populations are realized (Adams and Mclean 1985). In this regard, bioindicators not only can serve as early warning signals of impending ecosystem change, thus allowing time for remedial actions to be inftiated, but also can provide early detection of the effectiveness of these remedial actions.

\subsubsection{Advantages and Uses of Blological Indicators}

The principal advantages of using bioindicators, rather than other methods for quantifying ecological responses to stress, are as follows: (1) they can provide early warning signals of potential ecological effects because of their sensitivity to environmental change; (2) they can be used to identify causal mechanisms underlying observed effects at higher levels of biological organization, such as changes in population growth, reproductive success, and age structure; and (3) they are relatively easy to measure and cost-effective for long-term monitoring. These three advantages are discussed in detail in the following paragraphs.

Early warning signals of potential environmental stress. Of particular concern to environmental scientists and regulators are the long-term responses of organisms to environmental change (e.g., contaminant loading). The more important of these long-term responses (e.g., growth and reproductive capacity) respond relatively slowly to environmental change (Fig. 2); therefore, by the time these responses are observed in an aquatic ecosystem, undesirable effects (including decreases in biological productivity and diversity) may already have occurred. Such long-term responses may occur over periods of several years or biological generations (Fig. 2), and, within these extended time periods, a variety of natural and man-induced environmental factors can influence the integrity of biological communities. However, because 
OANL-DWG 89M-14026R

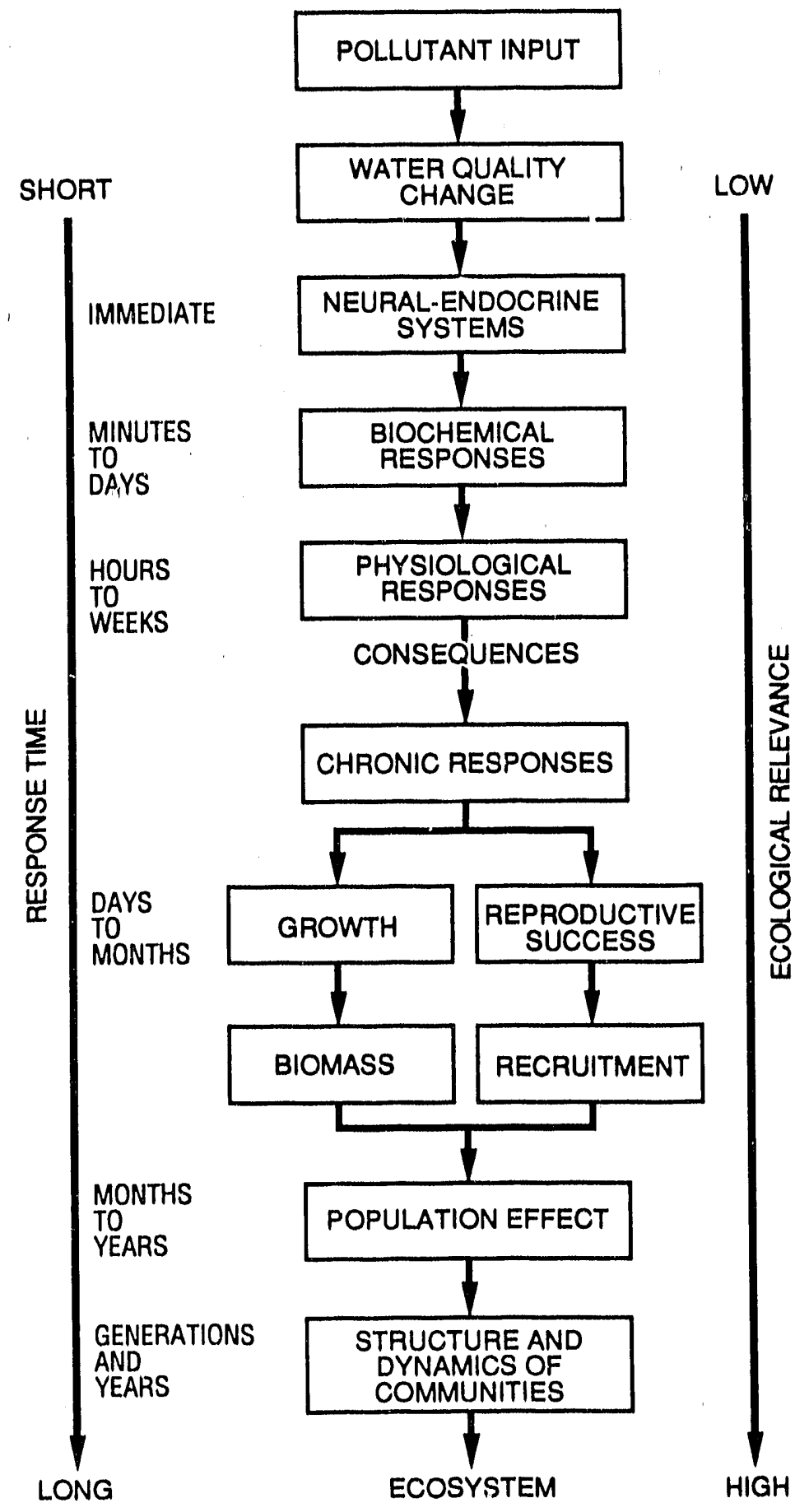

Fig. 2. Levels of blological responses in fish to changes in contaminant levels in surface waters, lllustrating the cont Inuum of these responses along gradients of time and ecological relevance. 
many environmental factors can contribute to and influence an ecological response, the major causes of a long-term ecological change may not be readily identified or quantified by measuring only long-term response varlables, such as fish species abundance or diversity.

The biochemical and physiological indicators used in this study respond within the same time frame as the environmental changes of concern (primarily water quality), and, because they immediately reflect those changes, they serve as early warnings of potential environmental effects. With bioindicators, changes observed in the biological integrity of Mitchell Branch (either beneficial or adverse) can be directly related to specific changes in environmental quality. For example, bioindicators can be used to evaluate (1) the effectiveness of remedial actions and (2) the biological effects of short-term, inadvertent contaminant discharges. Because many of the biological parameters normally measured in compliance monitoring programs (e.g., abundance and diversity of organisms) change relatively slowly, their usefulness as early warning signals of potential environmental change is limited, unless both short- and intermediate-term response indicators are measured concurrently.

Identification of mechanisms underlying long-term effects. In recent years, several methods have been developed to assess sublethal toxicity; most have focused on the suborganismal level (Buikema et a1 1982). Many of these biochemical and physiological measurements of toxicity have not proven useful because of insufficient information to establish causal relationships between these measurements and responses at the level of the whole organism, the population, and the community (Sprague 1976, Mehrle and Mayer 1980). In addition, the measurement of only suborganismal responses without concomitant organism- and population- level responses makes it difficult to determine whether biochemical or physiological responses to toxicants are deleterious or are in the normal range of adaptation of the organism (Mount and Stephan 1967).

The bioindicators that will be used in Task 3 represent a gradient of biological response times from relatively short-term to long-term (Fig. 2). Measurements of biological components over this gradient of 
response times will permit long-term changes in ecological systems to be identified and correlated with the principal fautors responsible for those changes. For example, a suite of short-term indicators will be measured in fish, including rapid-response blochemical variables and more intermediate-term responses, such as liver condition, histology of selectod organs, and lipid storage. With this approach, the shorterterm biological responses can be linked to the ecologically relevant long-term responses, such as growth, reproduction, and community abundance and diversity. By establishing cause-and-effect relationships between environmental change, short-term bioindicators, and long-term bioindicators, mechanisms primarily responsible for population- and community-level changes can be identified and quantified.

Cost effectiveness and ease of use. One of the major criteria for selecting the suite of biolndicators to be used in lasi: 3 is that the amount of effort (e.g., cost and time) allocated to the measurement of each indicator must be fustified by the quality and quantity of information provided by that indicator. Each bioindicator should be relatively easy to measure and should be cost-effective for application and use in long-term biological monitoring programs, such as the BMAP for Mitchell Branch. Once the relationship between short-term indicators (e.g., liver condition) and long-term responses (e.g., growth and abundance) is developed and its biological significance is established, these short-term indices will provide reliable documentation of the ecological status of Mitchell Branch and of the effectiveress of future remedial actions.

\subsubsection{Sampling Approach and Design}

Although resident adult sunfish (Lepomis auritus) are not currently found in sufficient numbers to support bioindicator studies, their collection from an uncontaminated reference site and introduction into Mi.tchell Branch is considered to be an appropriate and necessary procedure for evaluating responses of fish to contaminant-related stress in Task 3 of BMAP. Young-of-the-year redbreast sunfish were collected in the middle reaches of Mitche11 Branch on September 30, 1986 (Table 2). However, no sunfish were collected in two electrofishing 


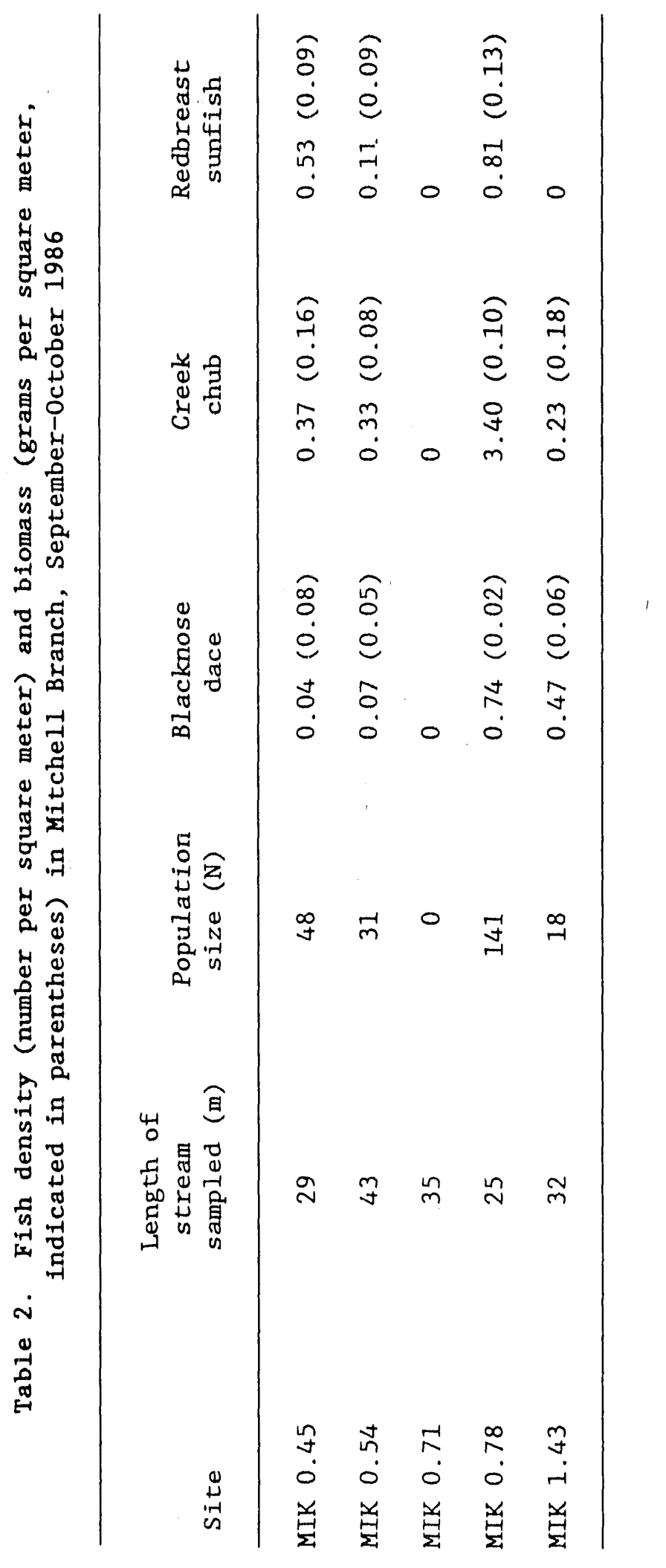


surveys conducted in the portion of lower Mitchell Branch immediately upstream from the NPDES monitoring welx, a site containing $-100 \mathrm{~m}$ of habitat ( 1 m deep with overhanging cover) that appears suitable for maintaining a population of adult sunfishes large enough to support these studies.

The absence of redbreast sunfish from lower Mitchell Branch may result from runoff containing leachate from the old classified burial ground that enters the stream through SD 190 at MIK 0.50 . Toxicity tests conducted October 30-November 6, 1986, indicated that effluent from this outfall was highly toxic to two other species: fathead minnows (Pimephales promelas) and Ceriodaphnia, a microcrustacean. Both species had 0 o survival in $100 \%$ effluent [L. M. Adams (currently L. A. Kszos), personal communication to W. J. Scheib, ORGDP, December 8, 1986]; the mean total chlorine concentration of the effluent was more than an order of magnitude greater than the "safe criterion" value of 0.03-0.005 ppm (De Graeve et al. 1979). In ambient toxicity tests conducted January 29-February 5, 1987 (Table 1), stream water collected at MIK 0.45 had a mean chlorine concentration $(0.08 \mathrm{ppm} \pm$ 0.05 ) that was significantly higher than the safe level. At that site Ceriodaphnia and fathead minnow survival were only 208 and $65 \%$, respectively, and reproduction and growth of both species were lowex than at any of the other sites tested [L. M. Adams (currently L. A. Kszos), personal communication to W. J. Scheib, ORGDP, February 25, 1987].

Introduced redbreast sunfish will be used for the bioindicator studies according to the following procedure. At various intervals after release, a subsample of the introduced fish will be collected for the bioindicator studies. The bioindicators to be measured will be chosen from the list in Table 3 and will represent selected response indicators at each major level of biological organization. This type of study will be conducted at least annually; however, if natural populations of sunfish occur in sufficient densities and sizes, then more-frequent monitoring or sampling will be conducted. Both the biological indicator and bioaccumulation tasks (Sect. 2.2) will utilize the same fish for analysis to minimize sampling and processing costs. 







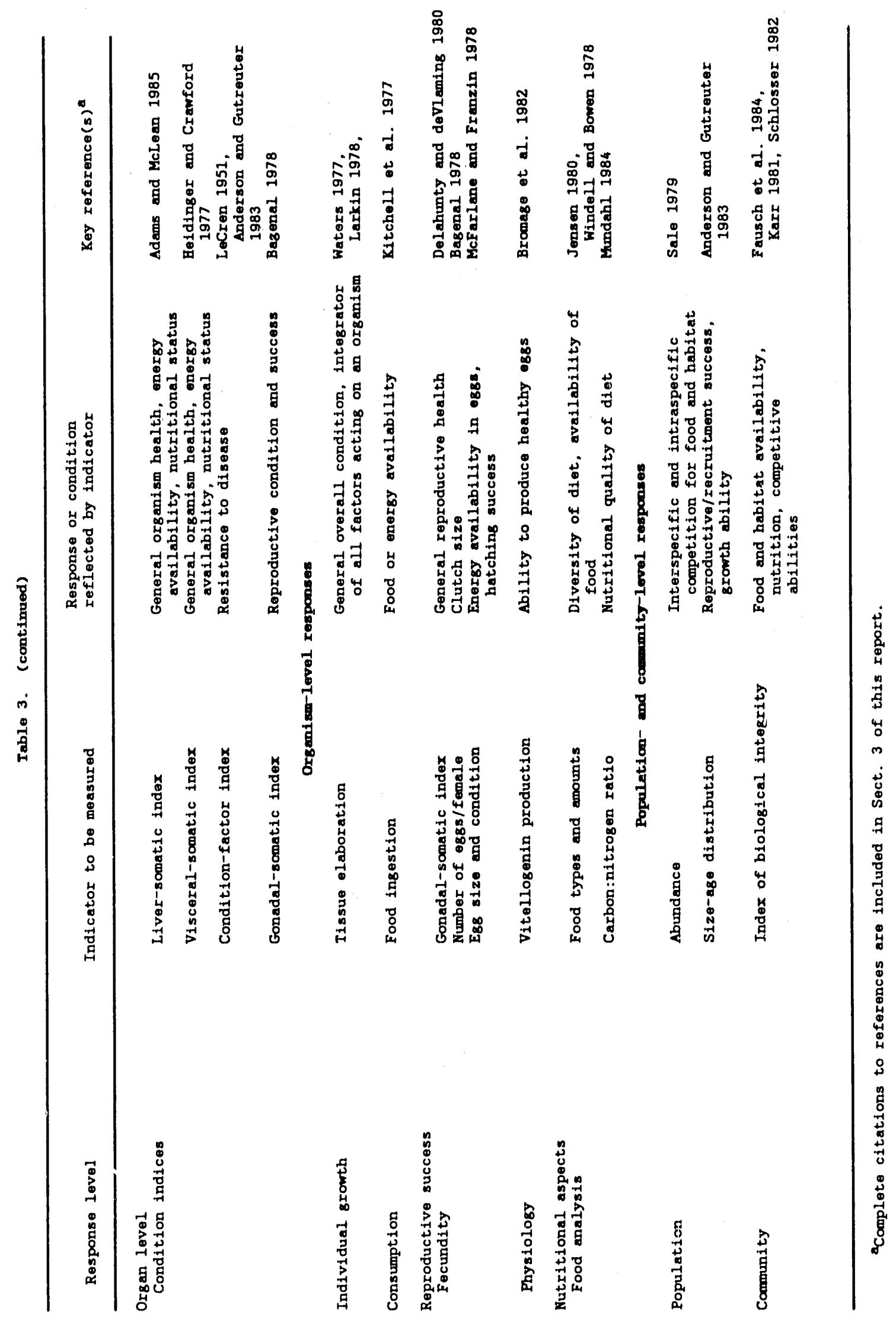




\subsection{INSTREAM MONITORING (TASK 4)}

\section{4 .1 Introduction}

The instream monitoring task will involve field sampling of the benthic invertebrate and fish populations in Mitchell Branch. The objectives of these studies are (1) to characterize spatial and temporal patterns in the distribution and abundance of these populati ns and (2) to document the effects of new pollution abatement facilities on community structure and function. Intensive sampling to characterize the benthic invertebrate and fish rommunities will be conducted during the first year. Based on the results of these and other studies (see Sects. 2.1 and 2.3), sampling frequencies and locations may be modified, as appropriate, during the monitoring phase of the program.

Analysis of the structure and function of benthic invertebrate communities provides a useful tool for evaluating the ecological effects of effluent discharges to streams (Sassun 1981). Because of their $10 \mathrm{w}$ motility and relatively long life cycles (several months to more than a year), benthic invertebrates integrate changes in the physicochemical environment of streams. Many benthic species spend a considerable portion of their cycle on or in stream sediments, resulting in long-term exposure to contaminants that accumulate in the sediments. Likewise, fish communities, which comprise species representing several trophic levels, integrate the effects of water quality and habitat degradation on lower trophic levels (e.g., benthic invertebrates) which are utilized for food. Because of these trophic interrelationships, the well-being of fish populations is often used as an index to water quality (e.g., Weber 1973, Greenson et al. 1977, Karr 1981). Moreover, statements about the condition of the fish community are better understood by the general public (Karr 1981).

\subsubsection{Benthic Macroinvertebrates (Subtask 4a)}

Benthic macroinvertebrates will be sampled monthly from designated riffle areas at six locations on Mitchell Branch (Table 1 and Fig. 1); the station farthest upstream will be used as a control site. The results obtained during the first year will be used to evaluate the possibility of reducing sampling frequency and the number of sampling 
locations. In addition to the upstream control site, several unimpacted reference streams, which are located both within and outside of the DOE Oak Ridge Reservation, will be sampled quarterly; the results will be compared with those for both the upstream control and all downstream sites. Use of additional reference streams with less-frequent sampling will provide a good comparison of natural seasonal variability occurring in unimpacted streams of this area. To accurately estimate species richness, a variety of microhabitats (e.g., leaf packs, undercut banks, pools, and riffles outside the study riffles) will be qualitatively sampled at each site in Mitchell Branch and the reference streams in March-Apri1 1987.

Three randomly selected quantitative benthic invertebrate samples will be taken at each site with a Surber sampler $\left(0.09 \mathrm{~m}^{2}\right.$ or $\left.1 \mathrm{ft}^{2}\right)$ fitted with a $363-\mu \mathrm{m}$-mesh collection net. The samples will be preserved in 808 ethanol, which will be replaced with fresh 808 ethanol within 1 week after collection of the samples. In the laboratory, benthic organisms will be separated from the debris in white enamel pans and identified to the lowest practical taxonomic level; ollgochaetes will be identified to family when possible. A blotted wet weight of each taxon will be obtained to the nearest $0.1 \mathrm{mg}$.

Species richness, density (total number of individuals per $0.09 \mathrm{~m}^{2}$ ), biomass (milligrams per $0.09 \mathrm{~m}^{2}$ ), and species diversity ( $\mathrm{H}^{\prime}$; Pielou 1977) of each site and the reference streans will be compared statistically with appropriate nonparametric or parametric procedures. Estimates of secondary production for each site will be obtained indirectly with production/biomass ratios $(P / B)$ obtained either from (1) a theoretical value of 5 and corrected for length of larval life (Waters 1977, Waters 1979, Benke 1979) or (2) published P/B ratios for specific taxa (e.g., Waters 1977, Kruger and Waters 1983, Benke et al. 1984). Where appropriate, water quality and ambient toxicity data will be used in data interpretations. 


\subsubsection{F1shes (Subtask 4b)}

\section{Preliminary survey of fishes in Mitchell Branch}

Five sites were chosen on Mitchell Branch for Initial evaluation of the fish communities (Table 2 and Fig. 1). Criteria used in the selection of these sites included both point-source discharge locations and area sources with possible seepage to surface waters (Sect. 1.2). These same sites were also selected for use in the benthic invertebrate studies and in the ambient toxicity testing program (Sect. 2.1.3).

Fish sampling was conducted at these sites on September 30 and October 1, 1986, using one Simith-Root Model 15A backpack electrofisher. Block-nets were used at the upper and lower ends of the 25 - to $50-\mathrm{m}$ reaches to isolate the populations. Fish were anesthetized with MS-222 (tricane methanesulfonate), identified, measured to the nearest $0.1 \mathrm{~cm}$ (total length), weighed to the nearest $0.1 \mathrm{~g}$ (for fish less than $100 \mathrm{~g}$ ) or gram (for individuals larger than $100 \mathrm{~g}$ ), and returned to the stream. Densities of each species were calculated from population estimates based on the removal method (Carle and Strub 1978) with three consecutive passes at each site.

This sampling in Mitchell Branch (Table 2) indicated fish populations were present at most of the sites selected to evaluate effluent effects. The fish communities consisted of at most three species: blacknose dace (Rhinichthys atratulus), creek chub (Semotilus atromaculatus), and immature redbreast sunfish (Lepomis auritus). The former two species are typically found in small first-and second-order streams in the area (Loar et al. unpublished data); redbreast sunfish, on the other hand, are generally found in large second-order and higher streams (Loar et al. 1991.). Fish densities at the sites varied from 0 to 3.4 individuals per square meter, with creek chubs being the most abundant species (Table 2). Biomass varied from 0 to $0.18 \mathrm{~g} / \mathrm{m}^{2}$, with the creek chub and redbreast sunfish alternating in dominance. The control site in the upper reaches of Mitchell Branch (MIK 1.43) lacked the redbieast sunfish, which probably reflects a separation from a breeding adult population and lack of suitable water depth. The absence of fish at MIK 0.71 may indicate an impact of coal yard runoff/boiler 
blowdown effluents that enter Mitchell Branch at the top of the site. Observations during routine benthic sampling also detected no fish at this site. Other sites below known discharge points (MIK 0.45 and MIK 0.54) also showed lower densities than at MIK 0.78 , a site of similar size and habitat located above SD 170, SD 180, and SD 190 (Fig. 1). These preliminary estimates indicate little difference between MIK 0.45 and MIK 0.54 ; therefore, one of these sites may be eliminated unless discrete effluent impacts are noted. Because MIK 1.43, the reference site, does not parallel the habitat structure of lower Mitchel1 Branch, another reference site will be added (e.g., Grassy Creek, a tributary of the Clinch River).

\section{Proposed studies}

Through the use of the procedures described in this report, fish communities will be sampled three times (January, April, and September) during the first year to estimate (by species) both population size (densities in numbers and biomass per unit area) and production. Annual production will be calculated using the method of Garman and Waters (1983). In addition, qualitative sampling in lower Mitchell Branch will be conducted, with an emphasis on determining the existence and size of adult redbreast populations.

The data generated in the population surveys will be used to estimate parameters at the community level (diversity, production, and abundance) and at the population level (length-weight relationship, production, and abundance). However, information is not avallable on parameters at the level of individuals within the population. To address this deficiency and strengthen the correlation between the instream monitoring task with its focus on communities and populations and the bioindicator studies (Task 3 ) with its focus on the individual, several additional parameters of a target species (either blacknose dace or redbreast sunfish) will be measured in the field during the second year of BMAP.

One parameter of individuals in a population is fecundity, or the number of ripening eggs in the female fust prior to spawning (Bagenal 1978), which provides a measure of potential reproductive success. 
Fecundity of either blacknose dace or redbreast sunfish will be estimated by gravimetric subsampling (Bagenal and Braum 1978). The number of eggs per female will be expressed as a function of fish length. This approach would be conducted for each site if blacknose dace are used, but would be limited to the lower reaches if an adult redbreast population is found.

Also, an evaluation of feeding preferences will be conducted on the same species used in the fecundity studies by obtaining data on diet composition, including variability in composition as a function of sampling location and seasom. If redbreast sunfish are chosen, stomachs will be flushed by inserting a small plastic tube $(0.5 \mathrm{~cm} \mathrm{O.D.)} \mathrm{into} \mathrm{the}$ gullet and repeatedly injecting water into the stomach using a rubber bulb with one-way valves. This nondestructive sampling technique is the same as that used by Loar et al. (1985) and is similar to the procedure described by Seaburg (1956). If the blacknose dace is chosen, then stomachs will be preserved from individuals taken for fecundity studies. Taxonomic identification of stomach contents will be made to the lowest practical taxon (genus, if possible). The studies on food habits of fishes in Mitchell Branch will provide general information on trophic interrelationships that can be used to construct community food webs or to compare biotic integrity (e.g., Karr 1981) with that of other streams of similar size and habitat. 


\section{REFERENCES}

Adams, S. M., and R. B. Mclean. 1985. Estimation of largemouth bass, Micropterus salmoides Lacepede, growth using the liver-somatic index and physlological variables. J, Fish. Biol. 26:111-126.

Adams, S. M., J. E. Breck, and R. B. McLean. 1985a. Cumulative stress-induced mortality of gizzard shad in a southeastern U.S, reservoir. Environ. Biol. Fishes 13:103-112.

Adams, S. M., C. A. Burtis, and J. J. Beauchamp. 1985b. Integrated and individual biochemical responses of rainbow trout (Salmo gairdnert) to varying durations of acidification stress. Comp. Biochem. Physiol. 82C:301-310.

Anderson, R. O., and S. J. Gutreuter. 1983. Length, welght, and assoclated structural indices. pp. 283-300. IN L. A. Nielson and D. L. Johnson (eds.), Fisheries Techniques. Southern Printing Co., Blacksburg, Virginia.

APHA (American Public Health Association), American Water Works Association, and Water Pollution Control Federation. 1981. Standard Methods for the Examination of Water and Wastewater, 15th ed. American Public Health Association, Washington, D.C. $1134 \mathrm{pp}$.

Ashwood, T. L., C. R. O1sen, I. L. Larsen, and P. D. Lowry. 1986. Sediment contamination in streams surrounding the Oak Ridge Gaseous Diffusion Plant. ORNL/TM-9791. Oak R.idge National Laboratory, Oak Ridge, Tennessee, $32 \mathrm{pp}$, and Appendices.

Bagena1, T. B. 1978. Aspects of fish fecundity. pp. 75-101. IN S. D. Gerking (ed.), Ecology of Freshwater Fish Production. John Wiley and Sons, New York. 520 pp.

Bagenal, T. B., and E. Braum. 1978. Eggs and early life history. pp. 165-201. IN T. Bagenal (ed.), Methods for Assessment of Fish Production in Fresh Waters, 3rd ed. IBP Handbook No. 3. Blackwell Scientific Publications, Oxford, England, $365 \mathrm{pp}$.

Benke, A. C. 1979. A modification of the Hynes method for estimating secondary production with particular significance for multivoltine populations. Limno1. Oceanogr. 24:168-171.

Benke, A. C., T. C. Van Arsda11, Jr., and D. M. Gillespie. 1984. Invertebrate productivity in a subtropical blackwater river: The importance of habitat and life history. Ecol. Monogr. 54:25-63.

Bromage, N. R., C. Whitehead, and B. Breton. 1982. Relationships between serum levels of gonadotrophin, oestradiol-17B, and vitellogenin in the control of ovarian development in the rainbow trout. Gen. Comp. Endocrinol. 47:366-376.

Buikema, A. L., B. R. Niederlehner, and J. Cairns, 1982. Biological monitoring. Part IV-Toxicity testing. Water Res, 16:239-262.

Carle, F. L., and M. R. Strub, 1978. A new method for estimating population size from removal data. Biometrics 34:621-630. 
DeGraeve, G, M., W. J. Blogoslawski, W. A. Brungs, J. A. Fava, B. J. Finlayson, T. P. Frost, T. M. Krischan, J. W. Meldrim, D. T. Michaud, R. E. Nakatani, and G. L. Seegert. 1979. Chlorine. pp. 67-75. IN R, V. Thurston, R, C. Russo, C. M. Fetterolf, Jr., T. A. Edsal1, and Y. M. Barber, Jr. (eds.), A Review of the EPA Red Book: Quality Criteria for Water. Water Quality Section of American Fisheries Society, Bethesda, Maryland.

Delahunty, G., and V. L. deVlaming. 1980. Seasonal relationships of ovary weight, liver weight and fat stores with body weight in the goldfish, Carassins auratus (L.). J. Fish. Biol. 16:5-13.

Eddy, F. B. 1981. Effects of stress on osmotic and lonic regulation in fish. pp. 77-102. IN A. D. Pickering (ed.), Stress and Fish. Academic Press, New York.

EPA (U.S. Environmental Protection Agency). 1971. Histochemical and cytophotometric assay of acid stress in freshwater fish. Water Pollution Control Research Series. EPA-18050-DXJ-05/71. Pennsylvania State University, University Park.

EPA (U.S. Envf ronmental Protection Agency). 1979. Assessment of clinical procedures to evaluate liver intoxication in fish. EPA-600/3-79-088. U.S. Environmental Protection Agency, Duluth, Minnesota, $106 \mathrm{pp}$.

EPA (U.S. Environmental Protection Agency). 1985. Technical support document for water quality-based toxics control. EPA-440/4-85-032. office of Water, U.S. Environmental Protection Agency, Washington, D.C.

Fausch, K. D., J. R. Karr, and P. R. Yant. 1984. Regional application of an index of biotic integrity based on stream fish communities. Trans. Am. Fish. Soc, 113:39-55.

Freeman, H. C., and D. R. Idler. 19\%3. Effects of corticosteroids on liver transaminases in two salmoids, the rainbow trout ( $S a l m o$ gairdneri) and the brook trout (Salvelinus fontinalis). Gen. Comp. Endocrinol, 20:69-75.

Garman, G. C., and T, F. Waters. 1983. Use of the size-frequency (Hynes) method to estimate annual production of a stream fish population. Can. J. Fish. Aquat. Sc1. 40:2030-2034.

Greeson, P. E., T. A. Ehike, G. A. Irwin, B. W. Lium, and K. V. Slack. 1977. Methods for collection and analysis of aquatic biological and microbiological samples. Book 5, Chap. A4. IN Techniques of Water-Resources Investigations of the United States Geological Survey. U.S. Government Printing Office, Washington, D.C.

Harrison, F. L., and J. R. Lam. 1985. Partitioning of copper among copper-binding proteins in the mussel Mytilus edulis exposed to soluble copper. Mar. Environ. Res. 16:151-163.

Heidinger, R. C., and S. D. Crawford, 1977. Effect of temperature and feeding rate on the liver-somatic index of largemouth bass (Micropterus salmoldes). J. Fish. Res. Board Can. 29:531-534.

Hinton, D. E., and J. A. Couch. 1985. Pathoblological measures of marine pollution effects. pp. 7-32. IN H. H. White (ed.), Concepts in Marine Pollution Measurements. Maryland Sea Grant College, College Park, Maryland. 
Hinton, D. E., M. W. Kenda11, and B. B. Silver, 1973, Use of histologic and histochemical assessments in the prognosis of the effects of aquatic pollutants. pp. 194-208. IN J. Calrns and K. L. Dickson (eds.), Blological Methods for the Assessment of Water Quality. ASTM Spec. Tech. Publ. 528. American Society for Testing and Materials, Philadelphia.

Hoffman, F. O., B. G. Blaylock, C. C. Travis, K. L. Danlels, E. L. Etnier, K. E. Cowser, and C. W. Weber, 1984. Preliminary screening of contaminants in sediments. ORNL/TM-9370. Oak Ridge National Laboratory, Oak Ridge, Tennessee. 86 pp.

Hopkins, C. C. E., J. V. Selring, and O. Nyholmen, 1984. Ecological energetics from total lipid and total protein: Fact and artifact using a gravimetric method for lipid and a bluret method for protein. Oceanogr. Mar. Biol. Annu. Rev, 22:211-261.

Horning, W. B., and C. I. Weber (eds.). 1985. Short-term methods for estimating the chronic toxicity of effluents and receiving waters to freshwater organisms. EPA/600/4-85/014. Environmental Monitoring and Support Laboratory, U.S. Environmental Protection Agency, Cincinnati.

Hughes, G. M, 1981. Effects of low oxygen and pollution on the respiratory systems of fish. pp. 121-146. IN A. D. Pickering (ed.), Stress and Fish. Academic Press, New York.

Jensen, A. J, 1980. The 'gut index': A new parameter to measure the gross nutritional state of arctic char, Salvelinus alpinns (L.) and brown trout, Salmo trutta L. J. Fish. Biol. 17:741-747.

Karr, J. R. 1981. Assessment of blotic integrity using fish communties. Fisheries $6: 21-27$.

Kitche11, J. F., D. J. Stewart, and D. Welninger, 1977. Application of a bioenergetics model to yellow perch (Perca flavescens) and walleye (Stizostedion vitreum vitreum). J. Fish, Res. Board Can. $344: 1922-1.935$.

Kruger, C. C., and T. F. Waters. 1983. Annual production of macroinvertebrates in three streams of different water quality. Ecology $64: 840-850$.

Larkin; P. D. 1978. Fisheries management: An essay for ecologists. Annu. Rev. Ėcol. Syst. 9:57-73.

Lech, J. J., M. J. Vodicnik, and C. R. Elcombe. 1982. Induction of monooxygenase activity in fish. pp. 107-148. IN L. J. Weber (ed.), Aquatic Toxicology. Raven Press, New York.

LeCren, E. D. 1951. The length-weight relationship and seasonal cycle in gonad weight and condition in the perch (Peroa fluviatilis). J. Anim. Ecol. 20:201-219.

Loar, J. M., M. J. Sale, G, F. Cada, D. K. Cox, R. M. Cushman, G. K. Eddlemon, J. L, Elmore, A, J. Gatz, P. Kanciruk, J. A. Solomon, and D. S. Vaughan. 1985. Application of habitat evaluation models in southern Appalachian trout streams. ORNL/TM-9323. Oak Ridge National Laboratory, Oak Ridge, Tennessee. $310 \mathrm{pp}$. 
Loar, J. M., S. M. Adams, L. J. Allison, J, M. Giddings, J, F, McCarthy, J. G. Smith, G. R, Southworth, and A. J, Stewart. 1989. The Oak Ridge Y-12 Plant Blological Monitoring and Abatement Program for East Fork Poplar Creek. ORNL/TM-10265. Oak Ridge Nationa1 Laboratory, Oak Ridge, Tennessee, $80 \mathrm{pp}$.

Loar, J. M., S. M. Adams, L. J. Allison, B, G. Blaylock, H. L. Boston, M. A. Huston, B. L. Kimmel, J. T. Kitchings, C. R, Olsen, J. G. Smith, G. R. Southworth, A. J. Stewart, and B. T, Walton. 1991. Oak Ridge National Laboratory Blological Monitoring and Abatement Program for White Oak Creek watershed and the Clinch River. ORNL/TM-10370. Oak Ridge National Laboratory, Oak Ridge, Tennessee. $142 \mathrm{pp}$.

McFarlane, G. A., and W. G. Franzin. 1978. Elevated heavy metals: A stress on a population of white suckers, Catostomus commersoni, in Hame11 Lake, Saskatchewan. J, Fish. Res, Board Can. 35:963-970.

Mcleay, D. J. 1973. Effects of a 12-hr and 25-day exposure to Kraft pulp mill effluent on the blood and tissues of Juvenile coho salmon, J, Fish. Res, Board Can. 30:395-400.

Mcleay, D. J. 1975. Sensitivity of blood cell counts in fuvenile coho salmon (Oncorhynchus kisutch) to stressors including sublethal concentrations of pulpmill effluent and zinc. J, Fish. Res. Board Can. 32:2357-2367.

Mehrle, P. M., and F. L. Mayer, 1980. Clinical tests in aquatic toxicology: State of the art. Environ. Health Perspect. $34: 139-143$.

Mount, D. I., and C. E. Stephan, 1967. A method for establishing acceptable toxicant limits for flsh-malathion and the butoxyethanol ester of 2,4-D. Trans. Am. Fish. Soc, 96:185-193.

Mudge, J, E., J. L. Dively, W. H. Neff, and A. Anthony. 1977. Interrenal histochemistry of acid-exposed brook trout, Salvelinus fontinalis (Mitchill). Gen. Comp. Endocrinol. 31:208-215.

Mundah1, N. D. 1984. Growth and condition of gizzard shad (Dorosoma cepedianum) in Action Lake, Ohio: Relationships to food quality. Ph.D. dissertation. Miami University, Oxford, Ohio.

NRC (National Research Council). 1981. Testing for Effects of Chemicals on Ecosystems. National Academy Press, Washington, D.C. $103 \mathrm{pp}$.

Parodi, S., M. Taningher, P. Boero, and L. Santi. 1982. Quantitative correlations amongst alkaline DNA fragmentation, DNA covalent binding, mutagenicity in the Ames test, and carcinogenicity for 21 compounds. Mutat. Res. 93:1-24.

Peltier, W. H., and C. I. Weber (eds.). 1985. Methods for measuring the acute toxicity of effluents to freshwater and marine organisms, 3rd ed. EPA 600/4-85-013. Environmental Monitoring and Support Laboratory, U.S. Environmental Protection Agency, Cincinnati.

Pielou, E. C. 1977. Mathematical Ecology. John Wiley and Sons, New York. 385 pp.

Plonka, A., and W. Neff. 1969. Mucopolysaccharide histochemistry of gill epithelial secretions in brook trout exposed to acid $\mathrm{pH}$. Proc, Pa. Acad, Sci, 43:53-56.

Sale, P. F. 1979. Habitat partitioning and competition in fish communities, pp. 323-331. IN H. Clepper (ed.), Predator-Prey 
Systems in Fisheries Management. Sporc Fishing Institute, Washington, D.C.

Sasson, A, M. 1981. Benthic macroinvertebrates, pp, 164-186.

IN J, M. Loar (ed.), Ecological Studies of the Blotic Communities

in the Virinity of the Oak Ridge Gaseous Diffusion Plant.

ORNL/TM-6714. Oak Ridge National Laboratory, Oak Ridge, Tennessee. $329 \mathrm{pp}$.

Schlosser, I, J. 1982. Fish communtey structure and function along two habitat gradients in a headwatar stream. Ecol. Monogr. 52:395-414.

Seaburg, K. G. 1956. A stomach sampler for live fish. Prog. Fish-Cult. $19(3): 137-139$.

Shugart, L., 1985. Quantitating exposure to chemical carcinogens: In viva alkylation of hemoglobin by benzo(a)pyrene. Toxicology $34: 211-220$.

Shulman, G. E. 1974. Life cycles of fish. Physiology and Biochemistry. John Wiley and Sons, New York. 258 pp.

Silbergeld, E. K. 1974. Blood glucose: A sensitive indicator of environmental stress in fish. Bull. Environ. Contam. Toxicol. $11: 20-25$

Southworth, G. R. (ed.). 1992. Ecological effects of contaminants and remedial actions in Bear Creek. ORNL/TM-11977. Oak Ridge National Laboratory, Oak Ridge, Tennessee, $310 \mathrm{pp}$.

Sprague, J, B. 1971. Measurement of pollutant toxicity to fish: Sublethal effects and "safe" concentrations. Water Res. 5:245-266.

Sprague, J. B. 1976. Current status of sublethal tests of pollutants on aquatic organisms. J. Fish. Res. Board Can. 33:1988-1992.

Steel, R, G. D., and J, H, Torrie, 1960. Principles and Procedures of Statistics. McGraw-H111 Book Company, Inc., New York. $481 \mathrm{pp.}$

Vetter, R. D., R. E. Hodson, and C. Arnold. 1983. Energy metabolism in a rapidly developing marine fish egg, the red drum (Sciaenops ocellata). Can, J, Fish, Aquat, Sc1, 40:627-634.

Waters, T, F. 1977. Secondary production in inland waters. Adv. Ecol. Res. $10: 91-164$.

Waters, T. F. 1979. Influence of benthos life history upon the estimation of secondary production. J, Fish. Res. Board Can. $36: 1425-1430$

Weber, C. I. (ed.). 1973, Biological field and laboratory methods for measuring the quality of surface waters and effluents. EPA-670/473-001. National Environmental Research Center, U.S. Environmental Protection Agency, Cincinnati.

Winde11, J. R., and S. H. Bowen. 1978. Methods for study of fish diets based on analysis of stomach contents. pp. 219-226. IN T. Bagenal (ed.), Methods for Assessment of Fish Production in Fresh Waters. Blackwe11 Scientific Publications, Oxford, England.

Yevich, P. P. 1981. The value of histopathology in the aquatic sciences. IN Proceedings of a Fish Health Workshop, Great Lakes Fishery Commission, Geneva Park, Ontario, Canada. 
APPENDIX A

LOCATION OF CORBICULA COLLECTION SITE AND RESULTS OF CHEMICAL ANALYSES 


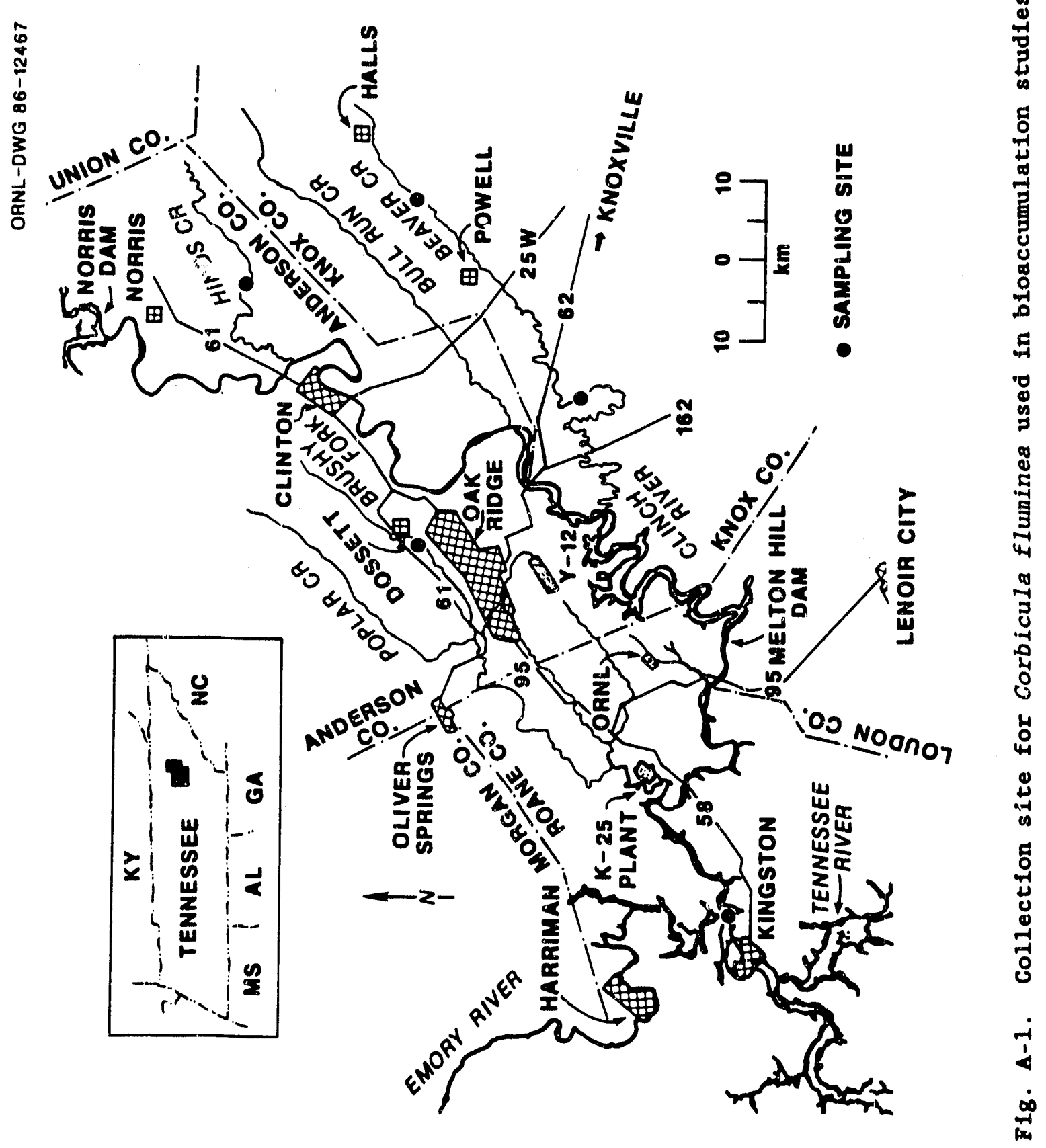


Table A-1. Concentrations (In micrograms per gram wet weight) of polycyclic aromatic hydrocarbons and polychlorinated biphenyls in 10-8 composite samples of clams (Corbicula fluminea) from Beaver Creek, a reference site for the Blological Monltoring and Abatement Program bloaccumulation studies

\begin{tabular}{|c|c|c|c|}
\hline \multirow[b]{2}{*}{ Compound } & \multicolumn{3}{|c|}{ Sample number } \\
\hline & 1 & 2 & 3 \\
\hline Naphthalene & 1.0 & $<0.45$ & $<0.45$ \\
\hline Acenaphthene & $<0.12$ & $<0.12$ & $<0.12$ \\
\hline Phenanthrene & 0.19 & $<0.12$ & $<0.12$ \\
\hline Anthracene & 1.7 & $<0.45$ & $<0.45$ \\
\hline Fluoranthene & $<0.05$ & 0.15 & $<0.05$ \\
\hline Pyrene & $<0.07$ & $<0.07$ & $<0.07$ \\
\hline Benzo(a) anthracene & $<0.02$ & 0.06 & $<0.02$ \\
\hline Benzo(b) fluoranthene & $<0.02$ & 0.08 & $<0.02$ \\
\hline Benzo(k)fluoranthene & $<0.01$ & 0.04 & $<0.01$ \\
\hline Benzo(a)pyrene & 0.011 & 0.045 & 0.017 \\
\hline Dibenz $(a, h)$ anthracene & $<0.02$ & $<0.02$ & $<0.02$ \\
\hline Benzo $(g, h, i)$ perylene & $<0.02$ & 0.07 & $<0.02$ \\
\hline Ideno $(1,2,3,-c, d)$ pyrene & $<0.09$ & $<0.09$ & $<0.09$ \\
\hline PCB 1254 & 0.06 & 0.03 & 0.08 \\
\hline РCB 1260 & 0.02 & 0.02 & 0.02 \\
\hline Total PCB & 0.08 & 0.05 & 0.10 \\
\hline
\end{tabular}


Table A-2. Results (In micrograms per gram wet weight)

of gas chromatographic mass spectrometry analysis of $10-g$ composite samples of clams (Corbicula fluminea) from Beaver Creek, a reference site for the Blological Monitoring and Abatement

Program bloaccumulation studies

\begin{tabular}{|c|c|c|c|}
\hline \multirow[b]{2}{*}{ Compound } & \multicolumn{3}{|c|}{ Sample number } \\
\hline & 1 & 2 & 3 \\
\hline Phenol & $<1$ & $<1$ & $<1$ \\
\hline Bis (2-chloroethyl)ether & $<1$ & $<1$ & $<1$ \\
\hline 2-Chlorophenol & $<1$ & $<1$ & $<1$ \\
\hline 1,3-Dichlorobenzene & $<1$ & $<1$ & $<1$ \\
\hline 1,4-Dichlorobenzene & $<1$ & $<1$ & $<1$ \\
\hline Benzyl alcuhol & $<1$ & $<1$ & $<1$ \\
\hline 1,2-Dichlorobenzene & $<1$ & $<1$ & $<1$ \\
\hline Bis (2-chloroisopropyl)ether & $<1$ & $<1$ & $<1$ \\
\hline$N$-nitrosodipropylamine & $<1$ & $<1$ & $<1$ \\
\hline Hexachloroethane & $<1$ & $<1$ & $<1$ \\
\hline Nitrobenzene & $<1$ & $<1$ & $<1$ \\
\hline Isophorone & $<1$ & $<1$ & $<1$ \\
\hline 2-Nitrophenol & $<1$ & $<1$ & $<1$ \\
\hline 2,4-Dimethylphenol & $<1$ & $<1$ & $<1$ \\
\hline Bis (2-chlorome thoxy) me thane & $<1$ & $<1$ & $<1$ \\
\hline 2,4-Dichlorophenol & $<1$ & $<1$ & $<1$ \\
\hline $1,2,4-\operatorname{Trichlorobenzene}$ & $<1$ & $<1$ & $<1$ \\
\hline Naphthalene & $<1$ & $<1$ & $<1$ \\
\hline 2-Methylnaphthalene & $<1$ & $<1$ & $<1$ \\
\hline $2,4,6$-Trichlorophenol & $<1$ & $<1$ & $<1$ \\
\hline 2-Chloronaphthalene & $<1$ & $<1$ & $<1$ \\
\hline Dimethylphthalate & $<1$ & $<1$ & $<1$ \\
\hline Acenaphthylene & $<1$ & $<1$ & $<1$ \\
\hline Acenaphthene & $<1$ & $<1$ & $<1$ \\
\hline 2,4-Dinitrophenol & $<5$ & $<5$ & $<5$ \\
\hline 4-Nitrophenol & $<5$ & $<5$ & $<5$ \\
\hline
\end{tabular}


Table A-2. (continued)

\begin{tabular}{|c|c|c|c|}
\hline \multirow{2}{*}{ Compound } & \multicolumn{3}{|c|}{ Sample number } \\
\hline & 1 & 2 & 3 \\
\hline Dibenzofuran & $<1$ & $<1$ & $<1$ \\
\hline 2,4-Dinitrotoluene & $<1$ & $<1$ & $<1$ \\
\hline 2,6-Dinitrotoluene & $<1$ & $<1$ & $<1$ \\
\hline Die thylphthalate & $<1$ & $<1$ & $<1$ \\
\hline 4-Chlorophenyl-phenylether & $<1$ & $<1$ & $<1$ \\
\hline Fluorene & $<1$ & $<1$ & $<1$ \\
\hline 4,6-Dinitro-2-methylphenol & $<5$ & $<5$ & $<5$ \\
\hline$N$-nitrosodiphenylamine & $<1$ & $<1$ & $<1$ \\
\hline 4-Br-phenyl-phenylether & $<1$ & $<1$ & $<1$ \\
\hline Hexachlorobenzene & $<1$ & $<1$ & $<1$ \\
\hline Pentachlorophenol & $<5$ & $<5$ & $<5$ \\
\hline Phenanthrene & $<1$ & $<1$ & $<1$ \\
\hline Anthracene & $<1$ & $<1$ & $<1$ \\
\hline Di-n-butylphthalate & $<1$ & $<1$ & $<1$ \\
\hline Fluoranthene & $<1$ & $<1$ & $<1$ \\
\hline Pyrene & $<1$ & $<1$ & $<1$ \\
\hline Butylbenzylphthalate & $<1$ & $<1$ & $<1$ \\
\hline 3,3-Dichlorobenzidine & $<2$ & $<2$ & $<2$ \\
\hline Benzo(a) anthracene & $<1$ & $<1$ & $<1$ \\
\hline Bis (2-ethylhexy1)phthalate & $<1$ & $<1$ & $<1$ \\
\hline Chrysene & $<1$ & $<1$ & $<1$ \\
\hline Di-n-octylphthalate & $<1$ & $<1$ & $<1$ \\
\hline Benzo(b) fluoranthene & $<1$ & $<1$ & $<1$ \\
\hline Benzo(k)fluoranthene & $<1$ & $<1$ & $<1$ \\
\hline Benzo(a)pyrene & $<1$ & $<1$ & $<1$ \\
\hline Indeno $(1,2,3-\mathrm{cd})$ pyrene & $<1$ & $<1$ & $<1$ \\
\hline Dibenz $(a, h)$ anthracene & $<1$ & $<1$ & $<1$ \\
\hline Benzo( $g, h, 1)$ perylene & $<1$ & $<1$ & $<1$ \\
\hline
\end{tabular}


Table A-2. (continued)

\begin{tabular}{lccc}
\hline & & Sample & number \\
\cline { 2 - 4 } Compound & 1 & 2 & 3 \\
\hline o-Cresol & $<1$ & $<1$ & $<1$ \\
p-Cresol & $<1$ & $<1$ & $<1$ \\
Benzoic acid & $<5$ & $<5$ & $<5$ \\
4-Chloroaniline & $<1$ & $<1$ & $<1$ \\
Hexachlorocyclobutadiene & $<1$ & $<1$ & $<1$ \\
p-Chloro-m-cresol & $<1$ & $<1$ & $<1$ \\
Hexachlorocyclopentadiene & $<1$ & $<1$ & $<1$ \\
2,4,5-Chlorophenol & $<5$ & $<5$ & $<5$ \\
2-Nitroaniline & $<5$ & $<5$ & $<5$ \\
3 -Nitroaniline & $<5$ & $<5$ & $<5$ \\
4 -Nitroaniline & $<5$ & $<5$ & $<5$ \\
Benzidine & $<5$ & $<5$ & $<5$ \\
1,2-Diphenylhydrazine & $<2$ & $<2$ & $<2$ \\
$N$-nitrosodimethylamine & $<5$ & $<5$ & $<5$ \\
& & & \\
\hline
\end{tabular}


ORNL/TM - 11965

INTERNAL DISTRIBUTION

1. S. M. Adams

2. L. J, Allison

3. A. G. Arp

4. T. L. Ashwood

5. W. D. Bostick

6. T. A. Bowers

7. G. F, Cada

8. S. W. Christensen

9. B. F. Clark

10. A. C. Coroneos

11. R. L. Fellows

12-14. J. M. Forstrom

15. R. E. Frounfelker

16. C. T. Garten, Jr.

17. C. W. Gehrs

18. J. L. Haymore

19. S. G. Hildebrand

20. R. L. Hinzman

21. M. A. Huston

22. B. L. Kimme 1

23. L. A. Kszos

24-33. J. M. Loar

34. J. B. Murphy

35. P. E. Osborne

36-37. P. T. Owen

38. M. J. Peterson

39. G. E. Rymer
40. M. G. Ryon

41. M. K. Savage

42. E. M. Schiliing

43. J. A. Shaakir-A1I

44-48. B, A. Shoemaker

49. L. R. Shugart

50. J. G. Smith

51. G. R. Southworth

52. A. J. Stewart

53. G. W. Suter

54. D. W. Swindle

55. W. Van Winkle

56. L. D. Voorhees

57. B. T. Walton

58. S. H. Welch

59. H. D. Whitehead, Jr.

60. Central Research Library

61. EMD Document Center

62-76. ESD Library

77. ER Document Management Center

78-79. Laboratory Records Dept.

80. Laboratory Records, ORNL-RC

81. ORNL Patent Office

82. ORNL Y-12 Technical Library

83. Y-12 Plant Central Files-RC

\section{EXTERNAL DISTRIBUTION}

84. S. Ahlstedt, Division of Water Resources, Tennessee Valley Authority, Norris, TN 37828

85. D. L. Buhaley, Environmental Operation Branch, Environmental Protection Division, SE-311, Department of Energy Oak Ridge Field Office, P.0. 2001, Oak Ridge, TN 37831

86. D. S. Day, Environmental Division, U.S. Department of Energy, Savannah River Operations Office, Box A, Aiken, SC 29802

87. P. H. Edmonds, Radian Corporation, 120 South Jefferson Circle, Oak Ridge, TN 37830

88. J. F. Franklin, Bloedel Professor of Ecosystem Analysis, College of Forest Resources, University of Washington, Anderson Hall (AR-10), Seattle, WA 98195

89. C. S. Gist, Environmental Protection Division, SE-31, Department of Energy Oak Ridge Field Office, P.O. Box 2001, Oak Ridge, TN 37831 
90. H. W. Hibbitts, Deputy Assistant Manager, Department of Environment, Safety, and Quality, SE-30, Department of Energy Oak Ridge Field office, P.O. Box 2001, Oak Ridge, TN 37831

91. D. R. Hopkins, U.S. Environmental Protection Agency, 345 Courtland Street, N.E., Atlanta, GA 30365

92. G. M. Hornberger, Professor, Department of Environmental Sclences, University of Virginia, Charlottesville, VA 22903

93. G. Y. Jordy, Director, Office of Program Analysis, Office of Energy Research, ER-30, G-226, U.S. Department of Energy, Washington, DC 20545

94. T. Joseph, Environmental Remediation Branch, Environmental Protection Division, SE-312, Department of Energy Oak Ridge Field office, P.0. 2001, Oak Ridge, TN 37831

95. W. A. Kocher, 1219 Riverbend Drive, Kingstion, TN 37763

96. E. C. Leming, Director, DOE Oversite Division, 761 Emory Valley Road, Oak Ridge, TN 37830-7972

97. G. J. Marciante, Environmental Protection Division, SE-31, Department of Energy Oak Ridge Field Office, P.0. Box 2001, Oak Ridge, TN 37831

98. A. D. McKinney, Chief, Environmental Services, P.0. Box 40747, Ellington Agricultural Center, Nashville, TN 37204

99. C. R. Olsen, Environmental Sciences Division, Office of Health and Environmental Research, ER-74, U.S. Department of Energy, Washington, DC 20585

100. R. H. Olsen, Vice President for Research, University of Michigan, Medical Science Building II, \#5605, 1301 East Catherine Street, Ann Arbor, MI 48109-0620

101. A. Patrinos, Acting Director, Environmental Sciences Division, Office of Health and Environmental Research, ER-74, U.S. Department of Energy, Washington, DC 20585

102. S. S. Perkins, c/o Labat-Anderson, Inc., Information Resource Center, Administrative Record File, 105 Broadway, Oak Ridge, TN 37830

103. S. P. Riddle, Environmental Restoration Division, EW-91, Department of Energy Oak Ridge Field Office, P.O. Box 2001, Oak Ridge, TN 37831-8541.

104. W. Schacher, Aquatic Habitat Protection Biologist, Tennessee Wildlife Resources Agency, 6032 W. Andrew Johnson Highway, Talbot, TN 37877

105. R. C. Sleeman, Environmental Restoration Division, EW-91, Department of Energy Oak Ridge Field Office, P.O. Box 2001, Oak Ridge, TN 37831-8541

106. F. J. Wobber, Environmental Sciences Division, Office of Health and Environmental Research, ER-74, U.S. Department of Energy, Washington, DC 20585

107. Office of Assistant Manager for Energy Research and Development, Department of Energy Oak Ridge Field Office, P.O. Box 2001, Oak Ridge, TN 37831-8600

108-117. Office of Scientific and Technical Information, P.0. Box 62, Oak Ridge, TN 37831 

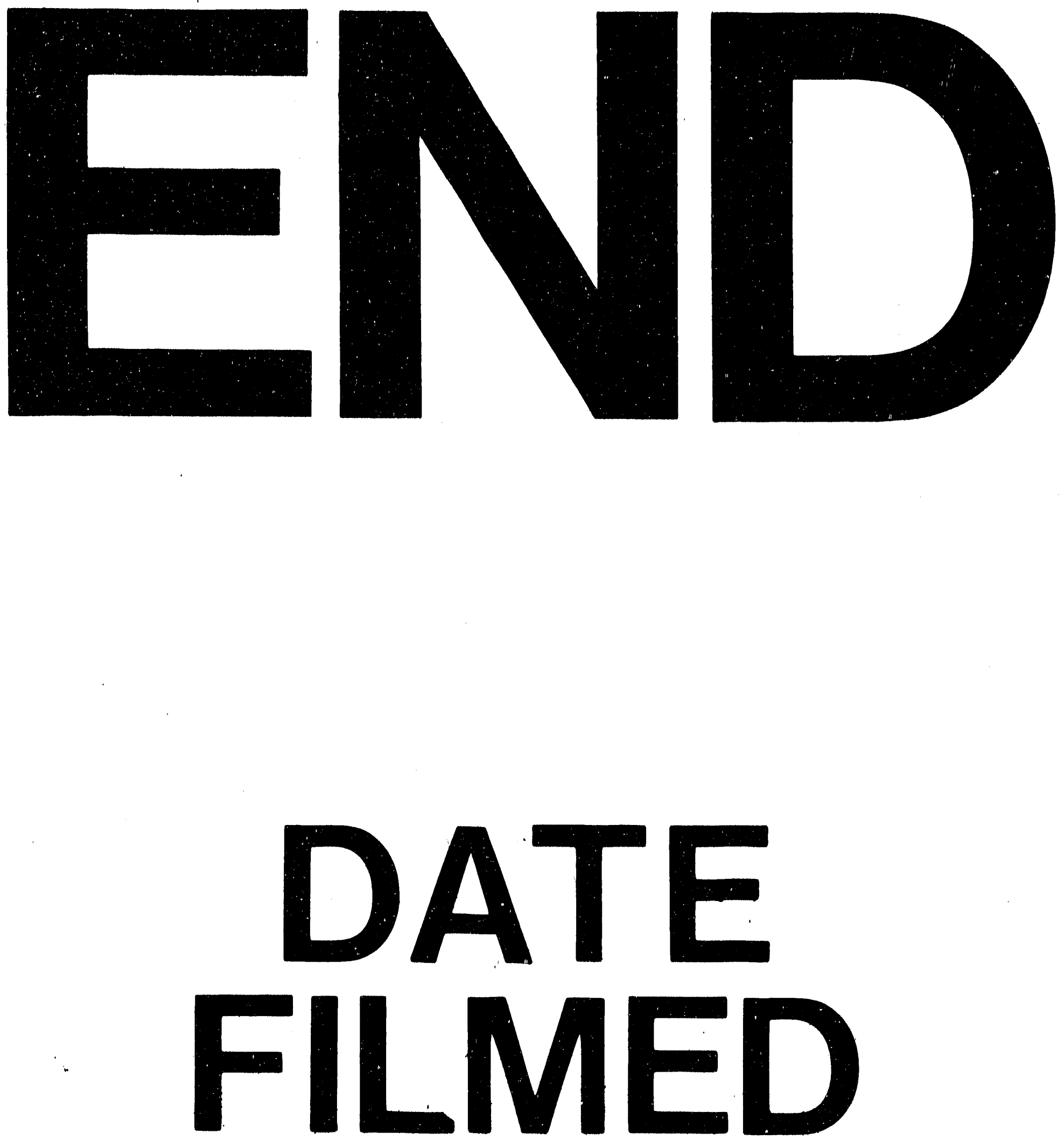

1

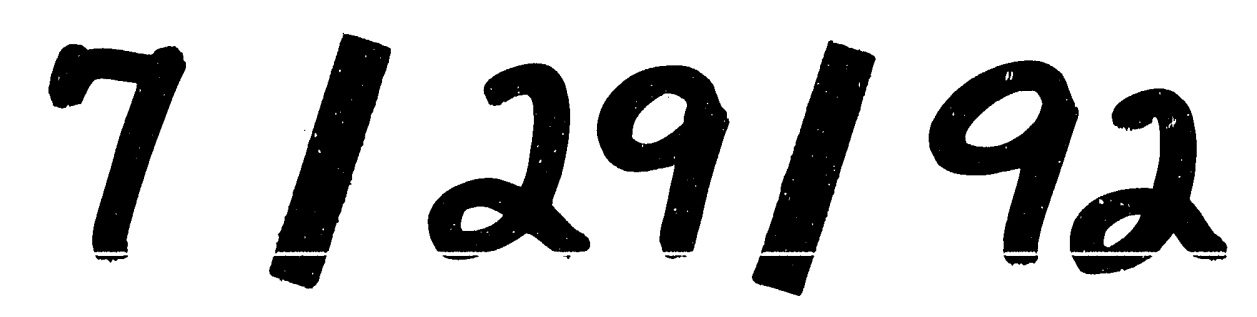


